\title{
IGN004 is an antibody-interferon-alpha fusion protein against a novel tumor-associated antigen with both direct anti-tumor and immunostimulatory effects
}

\author{
Kristopher K Steward ${ }^{*}$, Raj K Sachdev, Michael J Gresser, Sanjay D Khare
}

From 30th Annual Meeting and Associated Programs of the Society for Immunotherapy of Cancer (SITC 2015) National Harbor, MD, USA. 4-8 November 2015

\section{Background}

Antibody-interferon-alpha (IFN $\alpha$ ) fusion proteins represent a cancer therapeutic with properties of an antibodydrug conjugate and an immunotherapy, having both direct anti-tumor and immune-activating effects. We report the anti-tumor activity of IGN004, an antibody-IFNa fusion protein against a novel tumor-associated antigen expressed by many solid and liquid tumors.

\section{Methods}

IGN004 was evaluated against a panel of human nonsmall cell lung cancer (NSCLC), melanoma, multiple myeloma (MM), and AML cell lines. Binding was assessed by flow cytometry and immunohistochemistry (IHC). Anti-proliferative activity and $\mathrm{T}$ cell killing of tumor cells by TALL-104 effector cells were assessed by MTS assay. Human tumor xenografts were grown in immunodeficient mice.

\section{Results}

IGN004 unfused antibody bound to the majority of tumor cell lines and primary tumors assessed. Against tumor antigen-positive cells in anti-proliferation experiments, IGN004 demonstrated enhanced potency compared to unfused IFN $\alpha$ while reduced potency was observed in cells lacking antigen expression. IGN004 treatment upregulated MHC class I, PD-L1, and OX-40L on tumor cells. In an in vitro $\mathrm{T}$ cell killing assay using TALL-104 cells as effectors and A549 NSCLC cells as targets, the addition of IGN004 led to enhanced effector cell killing of tumor (69.2\% killing without IGN004 vs. 100\% killing with IGN004; $\mathrm{p}=0.001$ ). Importantly, IGN004 demonstrated robust in vivo efficacy against MM, NSCLC, AML, and melanoma xenografts, including patient-derived xenografts (PDX). Against U266 MM xenografts, IGN004 fusion protein caused complete regression of all tumors and achieved long-term survival in $62.5 \%$ of mice. Efficacy was tested against a panel of 14 NSCLC PDX tumors and IGN004 had a response rate of $64 \%$, including tumor regression in 29\%. In an AML PDX model, IGN004 treatment caused a reduction in AML cells in the blood, spleen and bone marrow. Against a PDX model of melanoma, IGN004 unfused antibody was ineffective while IGN004 fusion protein inhibited tumor growth.

\section{Conclusions}

IGN004 demonstrated robust anti-tumor activity against both solid and liquid tumors. Targeting of IFNa to the tumor cell surface via antibody resulted in enhanced potency of growth inhibition. The relative IFN $\alpha$ bioactivity is reduced against cells that do not express the target antigen, which may result in a broader therapeutic index. IGN004 demonstrated the ability to enhance the effector $\mathrm{T}$ cell mediated killing of NSCLC cells in an in vitro assay. Against human xenograft tumors, including PDX, IGN004 had robust in vivo anti-tumor efficacy. These results support the further development of IGN004 as a targeted cancer immunotherapy. 
doi:10.1186/2051-1426-3-S2-P245

Cite this article as: Steward et al:: IGN004 is an antibody-interferonalpha fusion protein against a novel tumor-associated antigen with both direct anti-tumor and immunostimulatory effects. Journal for ImmunoTherapy of Cancer 2015 3(Suppl 2):P245.

Submit your next manuscript to BioMed Central and take full advantage of:

- Convenient online submission

- Thorough peer review

- No space constraints or color figure charges

- Immediate publication on acceptance

- Inclusion in PubMed, CAS, Scopus and Google Scholar

- Research which is freely available for redistribution

Submit your manuscript at www.biomedcentral.com/submit
() Biomed Central 